\title{
МОВНИЙ ПРОСТІР НОМІНАЦІЙ ЖІНКИ
}

Рецензія на монографію: Архангельська A. Feтina cognita. Украӥнська жінка у слові й словнику /А. Архангельська. Київ: Видавничий дім Дмитра Бураго, 2019. 444 с. (Серія «Студії з українського мовознавства»).

DOI 10.31558/1815-3070.2020.40.1.19

УДК 811.161.2’27’246-055.2

Сучасне глобалізоване й інформатизоване життя більшості народів світу характеризується надзвичайно швидкими темпами розвитку. Безперечно, така соціодинаміка спричиняє відповідну лінгводинаміку: живі мови розвиваються більш інтенсивно. Життя вимагає все нових і нових номінацій реалій, понять, осіб, явищ, процесів, ознак, дій та станів. Саме тому з-поміж усіх основних рівнів у сучасних мовах найдинамічніше розвивається лексико-семантичний, а серед проміжних - словотвірний.

Українська нація, як і вся світова спільнота, щоденно зазнає істотних і різноманітних змін у майже всіх царинах своєї життєдіяльності. Найбільш характерними є перехід до інформаційної доби розвитку, значний і відчутний вплив глобалізаційних процесів, невпинний науково-технічний прогрес (особливо комп’ютеризація й інтернетизація), військові, соціальні та релігійні конфлікти, революції, економічні проблеми, хвороби (зокрема останнім часом коронавірус), пожвавлення міждержавних і міжособистісних контактів, міграція значних потоків людей, міжкультурна взаємодія та інші вагомі чинники зумовлюють істотні кількісні та якісні структурні, семантичні, функціонально-стилістичні та інші модифікації в українській мові кінця XX - початку XXI століття на всіх іiі рівнях.

Серед низки тенденцій, засвідчених в останні десятиліття в українській мові, помічено значну активізацію процесу фемінізації (моції). Фемінативи - підсистема морфологічних одиниць, чітко окреслених граматичним жіночим родом, альтернативні або парні аналогічним поняттям чоловічого роду.

Саме цій важливій і надскладній, проте актуальній мовознавчій проблемі сьогодення присвячено солідне монографічне дослідження Алли Архангельської 3 такою цікавою й інтригувальною назвою.

Як слушно зазначено в Передмові, книга стала результатом багаторічних спостережень та роздумів автора над одним із найбільш неоднозначно оцінюваних векторів мовної динаміки сьогодення - фемінізацією українського жіночого лексикону (с. 7). Дійсно, різноманітні назви зазначених осіб (як нових, так і актуалізованих) в аналізований період спричинили своєрідний "бум" в українському мовопросторі. Ставлення в державі та в українській діаспорі до переважної більшості фемінативів неоднозначне: від захоплення й пасивного сприйняття частиною мовців до категоричного несприйняття і критичного ставлення іншою. Однак так чи так аналізовані фемінативи стали знаком новітньої доби, іiі ціннісним виміром, виявом народної (нерідко й авторської) мовотворчості й нового мовомислення, «мовного смаку» оновленого українського культуромовного сус- 
пільства, яке визнало фемінізовані позначення жінки «справді українськими», актуальними, прикметною ознакою нашої мови, стану іiї словотвірної системи у взаємодії внутрішніх і зовнішніх ресурсів для творення нових номінативних одиниць, її динаміки з тенденцією до мовної аналогії та мовної аномалії (с. 7).

Глибоко усвідомлюючи складність і дискусійність названої вище проблеми, автор монографії намагається вивчити й зіставити різні погляди на фемінативи й фемінізацію українського жіночого лексикону, показати об'ємне бачення цього явища, поєднати його сьогодення з минулим і майбутнім, проаналізувати всі позитиви й можливі негативні впливи фемінізувальних процесів на «нове обличчя» нашої мови, окреслити свій погляд на новітні українські фемінативи, підкріпивши його якомога більшою кількістю мовних фактів і надійних аргументів (с. 8).

Метою книги А. Архангельської стала «мова - розмова в контексті спільної мови» 3 читачем, який може не поділяти висловлених у ній думок та поглядів. Її завдання - викликати читача на розмову, спонукати до діалогу, до власної оцінки цього надто яскравого, виразного й суперечливого явища сьогодення, аби не знехтувати його своєю байдужістю. Тож у книзі автор наважилася подати своє бачення проблеми й запропонувати читачеві задуматися над ключовими питаннями, дотичними до новітньої фемінізації жіночого лексикону: Яким же явищем $\epsilon$ в українській мові творення фемінізованих позначень жінки: помітним чи послідовним, тобто системним; обов'язковим чи необов'язковим; із високою мірою регулярності чи регулярним; історично сформованим як процес із стабільною активністю в словотвірній системі української мови чи таким, що розвивається за принципом «піків»? Чи справді фемінізація виявляла ознаки послідовності у період «розстріляного Відродження» і була як наша національна традиція насильницьки перерваною та зневаженою поколіннями мовознавців і лексикографів радянської доби? Як ставляться мовці й мовознавці до процесів і результатів сучасної неофемінізації? Як дискутується це питання в суспільстві й академічній спільноті? Чи є підстави настільки перебільшувати роль позамовного чинника й не зважати на мовні обмеження у сьогочасній фемінізувальній всенародній мовотворчості? Як оцінювати новітні й ревіталізовані фемінативи і якою міркою «виміряти» їх доцільність у нашій мові? Які шляхи виходу із ситуації, що склалася? (с 8-9).

Позитивної оцінки заслуговує, безперечно, структура монографії, яка є науково доцільною і композиційно чіткою, що визначено завданнями й методикою дослідження. Праця складається з передмови, чотирьох розділів, післямови, списку використаної літератури, переліку словників і довідників, предметного покажчика, анотації, відомостей про автора.

У першому розділі роботи ("Фемінізація та фемінативу науковій парадигмі антропоцентрично спрямованої лінвістики") грунтовно висвітлено основні теоретичні засади вивчення процесу фемінізації та фемінативів у науковій парадигмі антропоцентричної тенденції розвитку сучасної української мови. Передовсім чітко визначено метамову дослідження фемінативної підсистеми національної мови, з'ясовано роль словотвірної фемінізації (моції) в теорії номінації. Також скрупульозно і комплексно розглянуто різні стимули й чинники онов- 
лення пласту українського жіночого лексикону в контексті загальних процесів мовної та соціальної динаміки сьогодення, націоналізації (автохтонізації) мови, пошуки «свого», питомого й відмежування від «чужого», накинутого мові у радянську добу їі розвитку; простежено точки дотику фемінізувальних процесів 3 ідеями гендерної лінгвістики, із пуристичними інтенціями, впливами діаспорного варіанта української мови, процесами міфологізації нашого культурного і мовного минулого. Важливо акцентувати, що автор відзначає вплив на мовомислення сучасних українців і глобалізаційних процесів, тобто охоплення феміністичними ідеями і заклики до гендерної рівності на теренах нашої держави. Відрадно відзначити як важливий позитив рецензованої праці, що явище словотвірної фемінізації українського жіночого лексикону висвітлено 3 погляду його лінгвістичного статусу в тісній взаємодії гнучкої стабільності норми й узусу, наявних суперечностей між лексичною і стилістичною нормою з урахуванням «больових точок» новітньої фемінізації жіночого найменування, зокрема й питань українського комунікативного етикету.

Другий розділ репрезентованої праці ("Просторова і часова глибина фемінізувальних процесів в українській мові початку XX століття") присвячено виваженому аналізові просторової та часової глибини фемінізувальних процесів і фемінативів в українській граматичній традиції початку ХХ століття та лексикографічному доробку періоду українізації, належно окреслено головні тенденції, висвітлено способи творення й фіксацію мовних позначень жінки у словникарстві названого часового зрізу, виявлено долю тогочасних фемінативів у лексикографічних працях радянської та пострадянської доби, а також з'ясовано збережені тогочасні фемінативи в лінгвальній практиці української діаспори.

У третьому розділі монографії ("Фемінативи й фемінізація у мовній свідомості сучасних українців: соціолінгвістичний вимір") А. Архангельська здійснила грандіозну подвижницьку роботу з вивчення громадської думки носіїв мови щодо фемінізації й фемінативів у новітній українській мові, провівши три грунтовні соціолінгвістичні опитування з метою окреслити й узагальнити оцінку українським суспільством нових і відроджених назв жінок і процесів фемінізації у двох вимірах: із боку пересічних носіїв мови та з боку професіоналів найвищого рангу - працівників мовознавчих та літературознавчих інституцій НАН України, а також вдало провела опис, систематизацію і порівняння результатів анкетування.

Четвертий розділ роботи ("Україніш фемінініш", або що нам робити з фемінативами?") узагальнює стан і наслідки фемінізувальних процесів у сучасному українському мовленні та містить цікаві роздуми над аналізованими назвами й тенденціями, а головне - «що з цим робити». Докладно розглянуто відбиття інтенсивності названих вище процесів у мові мас-медіа - царині швидкого реагування на всі події і процеси в Україні та в світі, як найбільшій "кузні" створення ("кування") і "розкручування" нових слів на позначення осіб жіночої статі. Автор монографії слушно говорить про нагальну потребу діалогу, серйозної мовознавчої дискусії 3 приводу некерованої фемінізації українського жіночого називання. А. Архангельська висловила цікаві спостереження й думки щодо залучення фемінативів до нової 
редакції українського правопису. Заслуговує схвалення й те, що автор вдало використала в монографії показовий і повчальний чеський досвід розв'язання названого складного теоретичного й практичного питання сьогодення. Позитивно, що в роботі запропоновано шляхи розв'язання проблеми форсованої фемінізації українського жіночого лексикону.

Усі розділи пов'язані внутрішньою логікою та послідовністю викладу матеріалу. Вже сам перелік порушених у монографії питань і проблем засвідчує неабияку іiі наукову цінність. А. Архангельська висловлює цікаві власні думки або цитує відомих учених про вживання фімінативів в узусі та порушує надзвичайно складну проблему їх унормування. Слушно говорить про можливість варіантних реалізацій норми, що закладені в особливостях системи і структури української як і будь-якої іншої мови. Автор акцентує на ролі естетики як фільтра для становлення норми, а також розглядає поняття "мовної терапії" та "мовної гігієни". Тонко підмічено дослідником, що при оцінюванні новітніх фемінативів часто маємо виразний незбіг словотвірної та лексичної норм (а ми б додали - також і стилістичної). Не викликають заперечення подані А. Архангельською переконливі факти семантичної невідповідності нових назв жінок одиницям на позначення чоловіків. Виділено ще один важливий рушій активізації фемінативів в новітньому українському мовопросторі - мода на їх уживання в художніх, а також, як це не дивно, і в нехудожніх стилях - в офіційно-діловому та науковому.

Варто відзначити грандіозну збирацьку роботу цікавого і переконливого фактичного матеріалу, його чітку класифікацію здійснену автором. Узагальнювальний аналіз фемінної лексики проведено на надійному науково-теоретичному грунті. Про це також переконливо свідчить розлогий список використаної літератури (459 позицій) та словників і довідників (56 джерел), дані яких доречно використано автором у процесі аналізу явища новітньої фемінізації українського жіночого лексикону в ретроспективі й у пошуку перспективи, відбиваючи широкий спектр цікавих концепцій, думок та підходів до аналізованого явища й дотичних до нього питань і проблем.

Звичайно, як і кожна об'ємна та неординарна робота, попри ретельність ії опрацювання, монографія А. Архангельської не позбавлена окремих недоглядів. Загалом книгу написано грамотно, літературною мовою, хоча подекуди, на жаль, помічено окремі відступи від чинних норм, зокрема стилістичного плану: невдалий вибір слів, неточне слововживання: свого роду містифікацію (див. стор. 82) - потрібно своєрідну; прескриптивна норма базується на дескриптивній нормі (див. стор. 94) - потрібно трунтується; мовної системи в иілому (див. стор. 372) - потрібно загалом та ін., а також окремі фоностилістичні недогляди (див. стор. $65,83,371$ тощо).

Проте висловлені вище зауваження і побажання в ніякому разі не знижують цінності праці, яка порушує злободенну проблематику, є самостійною, новаторською і надзвичайно важливою.

Належно представлено огром важливого і сучасного текстового матеріалу, стиль викладення цілком доступний, А. Архангельська чітко й зрозуміло (а головне - неупереджено) формулює основні положення й висновки, виважено 
обгрунтовує власну позицію. Тому не буде перебільшенням, коли скажемо у висновку, що українська мовознавча наука, а також славістика, збагатилися надзвичайно актуальним, цікавим і корисним дослідженням, яке заслуговує найвищої оцінки й становить вагомий внесок у сучасну теорію і практику ономасіології.

Олександр Стишов 